\title{
KESEHATAN IBU HAMIL DARI PERSPEKTIF SOSIAL CULTURE/BUDAYA
}

\begin{abstract}
Alifya Nurul Izzha Deddy
Universitas Islam Negeri Alauddin Makasaar

Email: alifyanurulizzha@gmail.com

\section{PENDAHULUAN}

Indonesia sehat adalah suatu gambaran kondisi Indonesia di masa depan, yakni masyarakat, bangsa, dan negara yang ditandai oleh penduduknya hidup dalam lingkungan dengan perilaku hidup sehat, memiliki kemampuan menjangkau pelayanan kesehatan yang bermutu secara adil dan merata, serta mencapai derajat kesehatan yang setinggi-tingginya di seluruh wilayah Negara Kesatuan Republik Indonesia (NKRI). Visi Depkes 2010-2014 yaitu masyarakat sehat yang mandiri dan berkeadilan (Depkes, 2010). Setiap negara memiliki tolak ukur dalam pencapaian derajat kesehatan, diIndonesia salah satu indikator dalam pencapaian derajat kesehatan masyarakat sehat yang mandiri dan berkeadilan sesuai dengan visi Depkes 2010 -2014 adalah dengan target menurunkan kematian Ibu (AKI) dan angka kematian bayi (AKB) yang masih tinggi (Ronald, 2011).

World Health Organization (WHO) memperkirakan angka kematian maternal di Indonesia diperkirakan mencapai 100 sampai 1.000 lebih per 100.000 dari kelahiran hidup.Hasil laporan kemajuan pencapaian Millennium Development Goals (MDGs) tahun 2007 Angka Kematian Ibu (AKI) di Indonesia masih mencapai 307 per 100.000 kelahiran hidup, tertinggi di Asia Tenggara (Sukowati, 2008). Dan berdasarkan Survei Demografi dan Kesehatan Indonesia (SDKI) pada tahun 012 jumlah AKI di Indonesia yaitu 359 per 100 ribu kelahiran hidup (Depkes, 2012). Berdasarkan laporan dari profil kab/kota AKI maternal yang dilaporkan di Sumatera Utara tahun 2012 yaitu 106/100.000 kelahiran hidup.(Profil Kesehatan Sumatera Utara Tahun 2012).
\end{abstract}

Diperkirakan 50.000.000 ibu setiap tahunnya mengalami masalah kesehatan yang berhubungan dengan komplikasi -komplikasi kehamilan, persalinan dan nifas. Komplikasi yang ada kaitannya dengan kehamilan berjumlah sekitar $18 \%$ dari jumlah global penyakit yang di derita wanita pada usia reproduksi. Dan diperkirakan $40 \%$ wanita hamil akan mengalami komplikasi sepanjang kehamilannya (Ronald, 2011). Menurut Ronald (2010) diperkirakan dari setiap ibu yang meninggal dalam kehamilan, karena menderita komplikasi, diakibatkan karena adanya penyebab langsung dan tidak langsung dari kematian ibu tersebut. Penyebab utama kematian ibu yaitu adanya perdarahan (25\%), sepsis (15\%), hipertensi dalam kehamilan (12\%), partus macet (8\%), komplikasi aborsi tidak aman (13\%), dan penyebab lain (8\%) maka penyebab tidak langsung dari kematian ibu seperti anemia. Sebab kematian ibu, mulai dari kehamilan itu sendiri terdapat banyak masalah yang salah satunya kehamilan dengan mitos - 
mitos yang baik sadar atau tidak disadari selalu hidup secara turun temurun dalam masyarakat. Mitos-mitos kehamilan ini dapat memberikan pengaruh bagi perilaku ibu hamil baik itu positif maupun negatif hingga 73 mempengaruhi kunjungan pemeriksaan kehamilan.

Berdasarkan Profil Kesehatan Sumatera Utara Tahun 2012 Cakupan pemeriksaan kehamilan ibu hamil di Sumatera Utara sejak tahun 2007 mengalami kenaikan dari 77,95\% menjadi 85,92\% ditahun 2012, yaitu untuk cakupan KI sebesar 92,74 \% dan untuk cakupan K4 sebesar 85,92 \% dari 25 kabupaten dan 8 kota yang ada di Sumatera Utara namun peningkatan ini terkesan lambat karena peningkatkannya hanya sekitar $2 \%$ setiap tahun. Dengan peningkatan seperti ini dikhawatirkan Sumatera Utara tidak mampu mencapai target SPM bidang kesehatan yaitu $95 \%$ di tahun 2015 .

\section{Pengetahuan Ibu Hamil Dengan Keikutsertaan}

Pengetahuan ibu hamil tentang kehamilan pada umumnya masih kurang $(68,51 \%)$ dan yang berpengetahuan baik hanya 4 orang $(7,41 \%)$. Pengetahuan ibu hamil yang kurang inilah kemungkinan masih dipercayainya berbagai hal yang menyangkut tentang larangan/pantangan makanan ataupun melakukan suatu tindakan/ aktivitas (pantangan perilaku).

Kelas ibu hamil adalah salah satu bentuk pendidikan prenatall yang dapat meningkatkan pengetahuan ibu hamil dan perubahan perilaku positif sehingga ibu diharapkan memeriksakan kehamilan dan melahirkan ketenaga kesehatan. Kelas Ibu hamil merupakan sarana belajar bersama yang diikuti oleh ibu hamil agar memperoleh pengetahuan yang cukup sehingga dapat mencegah komplikasi dan meningkatkan cakupan K4. Tujuan diadakannya kelas ibu hamil adalah untuk menambah pengetahuan ibu tentang kesehatan ibu dan anak, sehingga dapat mengurangi terjadinya angka kematian ibu dan angka kematian bayi (DepkesRI,2009;h.4).

Pertemuan kelas ibu hamil dilakukan 3 kali pertemuan selama hamil atau sesuai dengan hasil kesepakatan fasilitator. Tingkat pengetahuan seseorang biasanya akan mempengaruhi pola pikirnya, baik terhadap kehidupan social maupun kesehatan. Seseorang dengan pengetahuan yang baik akan memprioritaskan kesehatan dalam hidupnya dengan partisipasinya dalam mengikuti kelas ibu hamil dari pada orang yang pengetahuan yang kurang baik (DepkesRI,2009;h.4).

Keterbatasan pengetahuan akan menyulitkan seseorang memahami pentingnya pemeliharaan kesehatan dan perubahan perilaku seseorang kearah yang menguntungkan kesehatan. Berbagai hal yang memepengaruhi tinggi rendahnya pengetahuan dan partisipasi ibu hamil dalam kelas ibu hamil, diantaranya tingkat pengetahuan ibu hamil dan partisipasi ibu hamil tentang kelas ibu hamil masih banyak yang kurang berpartisipasi dalam kelas ibu hamil. Hal ini dikarenakan waktu pelaksanaan kelas ibu hamil yang kurang efektif dan tempat pelaksanaan ibu hamil. Hambatan dari kurangnya partisipasi dalam kelas ibu hamil dikarenakan ibu hamil tidak tahu adanya kelas ibu hamil di wilayahnya, serta ibu hamil yang bekerja. Adapun dampak bila ibu hamil tidak ikut kelas ibu hamil selama kehamilannya tidak begitu signifikan, akan tetapi ibu 
hamil tersebut tidak ada perubahan dalam pemahaman, sikap dan perilaku ibu hamil seperti perawatan selama kehamilan,sehingga dalam mempersiapkan persalinannya kurang, serta jika ada resiko pada ibu hamil tersebut tidak langsung terdeteksi oleh tenaga kesehatan (DepkesRI,2009;h.3).

\section{Hubungan sikap dengan pertolongan persalinan pada tenaga kesehatan}

Berdasarkan hasil uji statistik antara pengetahuan dengan pertolongan persalinan pada tenaga kesehatan terdapat hubungan yang bermakna dengan nilai $\mathrm{p}=0,015$. Menurut asumsi peneliti kecenderungan sikap ibu memilih melakukan pertolongan persalinan pada tenaga non kesehatan adalah dipengaruhi oleh pengetahuan yang kurang sehingga sikapnya menjadi negatif untuk melakukan persalinan pada tenaga non kesehatan. Faktor budaya dan budaya keluarga juga turut memberikan pengaruh terhadap sikap ibu dalam memilih pertolongan persalinan. Untuk itu upaya -upaya kesehatan melalui penyuluhan dan pendampingan diharapkan bisa merubah sikap ibu untuk dapat melakukan pertolongan persalinan pada tenaga kesehatan profesional.

Dari hasil kuesioner didapatkan bahwa sebagian ibu mempunyai sikap negatif terhadap pertolongan kesehatan dan hal ini mempengaruhi ibu untuk lebih bersalin pada tenaga non kesehatan, ini dibuktikan dengan hasil kuesioner dimana pertolongan persalinan lebih tinggi pada tenaga non kesehatan dibandingkan tenaga kesehatan. Sikap merupakan reaksi atau respon yang masih tertutup dari seseorang terhadap suatu stimulus atau objek. Sikap merupakan kesiapan untuk kesediaan, untuk bertindak dan bukan merupakan pelaksanaan motif tertentu. Sikap belum merupakan predisposisi suatu perilaku.

\section{Persepsi Budaya Terhadap Kehamilan dan Persalinan}

Pada dasarnya masyarakat mengkhawatirkan masa kehamilan dan persalinan. Masa kehamilan dan persalinan di deskripsikan oleh Bronislaw Malinowski menjadi fokus perhatian yang sangat penting dalam kehidupan masyarakat. Ibu hamil dan yang akan bersalin dilindungi secara adat, religi, dan moral dengantujuan untuk menjaga kesehatan ibu dan bayi. Mereka menganggap masa tersebut adalah masa kritis karena bisa membahayakan janin dan/atau ibunya. Masa tersebut direspons oleh masyarakat denganstrategi-strategi, seperti dalam berbagai upacara kehamilan, anjuran, dan larangan secara tradisional(Malinowski, Bronislaw, 1927: 76).

Permasalahan yang cukup besar pengaruhnya pada kehamilan adalah masalah gizi. Permasalahan gizi pada ibu hamil di Indonesia tidak terlepas dari faktor budaya setempat. Hal ini disebabkan karena adanya kepercayaan-kepercayaan dan pantangan-pantangan terhadap beberapa makanan. Kepercayaan bahwa ibu hamil dan postpartum pantang mengkonsumsi makanan tertentu menyebabkan kondisi ibupostpartum kehilangan zat gizi yang berkualitas. Sementara, kegiatan mereka sehari-hari tidak berkurangditambah lagi dengan pantanganpantangan terhadap beberapa makanan yang sebenamya sangat dibutuhkan oleh wanita hamil tentunya akan berdampak negatif terhadap kesehatan ibu dan janin. Kemiskinan masyarakat akan berdampak pada penurunan pengetahuan dan informasi, dengan kondisi ini keluarga, khususnya 
ibu akan mengalami resiko kekurangan gizi, menderita anemia dan akan melahirkan bayi berat badan lahir rendah. Tidak heran kalau anemia dan kurang gizi pada wanita hamilcukup tinggi terutama di daerah pedesaan.

Dapat dikatakan bahwa persoalan pantangan atau tabu dalam mengkonsumsi makanan tertentu terdapat secara universal di seluruh dunia. Pantangan atau tabu adalah suatu larangan untuk mengkonsumsi jenis makanan tertentu, karena terdapat ancaman bahaya terhadap barang siapa yang melanggarnya. Dalam ancaman bahaya ini terdapat kesan magis, yaitu danya kekuatan superpower yang berbau mistik yang akan menghukum orang-orang yang melanggar pantangan atau tabu tersebut. Tampaknya berbagai pantangan atau tabu pada mulanya dimaksudkan untuk melindungi kesehatan anak-anak dan ibunya, tetapi tujuan ini bahkan ada yang berakibat sebaliknya, yaitu merugikan kondisi gizi dan kesehatan.

Secara universal adat atau kepercayaan tentang makanan yang terkait dengan tabu ada di seluruh negara, baik di negara yang teknologinya sudah maju maupun di negara berkembang. Di Meksiko seorang wanita hamil dan setelah melahirkan dilarang makan makanan yang bersifat "dingin". Masyarakat CinaAmerika menganut teori "Yin" dan "Yang" sehingga wanita yang baru melahirkan harus dilindungi dariangin dan dilarang makan makanan dan minuman yang bersifat dingin, dan minum obat. Di beberapa negara berkembang umumnya ditemukan larangan atau pantangan tertentu bagi wanita hamil Di Indonesia wanita hamil dan setelah melahirkan dilarang makan telur, daging, udang, ikan laut dan lele, keong,daun lembayung, buah pare, nanas, gula merah, dan makanan yang digoreng dengan minyak (Afiyah SriHarnany, 2006: 45).

\section{Interaksi Sosial Ibu Hamil}

Interaksi sosial ibu hamil mayoritas ibu hamil memiliki interaksi sosial dengan suami dan tetangga (100\%), sementara itu interaksi dengan orang tua $(27,77 \%)$ dengan mertua $(12,96 \%)$ dengan bidan $(11,11 \%)$ dengan sesama ibu hamil (9,25\%). Menurut Ana (2010) dukungan suami dalam kehamilan sangat penting dengan memberikan perwujudan dalam hal perhatian, dalam hal mendampingi, merawat, menemani dan menjadi pihak yang membantu ibu dalam membuat keputusan bersama dan disebutkan juga bahwa dalam kehamilan di butuhkan orang lain seperti keluarga terdekat ataupun pihak lainnya yang sekiranya untuk turut membantu. Hal ini sejalan dalam penelitian Fauziah tentang mitos kehamilan di Kecamatan Meurebo Kabupaten Aceh Barat Nanggroe Aceh Darussalam yang mengatakan bahwa interaksi sosial perempuan hamil sangat di perlukan dalam kesehariannya, baik berupa dukungan-dukungan psikologis, perhatian, kasih sayang, pengorbanan dan empati terutama dari pihak suami dan pihak keluarga-keluarga terdekat pada perempuan hamil tersebut. Hal ini di tinjau dari segi psikologis, karena jika perempuan hamil akan mengalami perubahan kondisi fisik dan emosional yang cukup kompleks yang di sebabkan adanya perubahan hormon dan proses adaptasi terhadap penyesuaian pola hidup dengan proses kehamilan yang terjadi sehingga memerlukan dukungan dan perhatian orang -orang terdekatnya yaitu seperti dengan pihak suami dan pihak keluarga terdekat. Menurut Wahit (2012) Interaksi sosial berlandaskan antara kelompok manusia dengan antara elompok 
sebagai kesatuan dan yang sifatnya tidak menyangkut pribadi. Interaksi sosial antara kelompok kelompok manusia dapat terjadi di keluarga dan di masyarakat yang di dasarkan pada berbagai faktor yaitu adanya faktor imitasi,faktor sugesti,faktor identifikasi dan faktor simpati.

Saat ada keluhan tentang kehamilannya, ibu-ibu hamil berdasarkan hasil penelitian hanya 7 orang $(12,96 \%)$ yang berinteraksi dengan bidan. Ibu hamil malah lebih seang berinteraksi atau meminta nasehat dari orang tua ataupun mertuanya, padahal sumber informasi yang lebih baik di dapat dari Bidan (petugas Kesehatan). Kebiasaan berinteraksi dengan tetangga juga kemungkinan penyebab semakin berkembangnya mitos-mitos ataupun budaya yang tidak sesuai dengan kesehatan ibu hamil diyakini oleh ibu hamil itu sendiri. Rendahnya kunjungan antenatal $(59,25)$ yaitu persentase ibu hamil yang tidak pernah melakukan ANC kemungkinan juga dipengaruhi sistem interaksi di masyarakat yang menyakini informasi ataupun budaya yang dianut oleh teman/tetangga.

\section{Budaya Berpantang Makan dan Berperilaku Saat Hamil}

Mayoritas ibu hamil berpantang makan ikan di usia > 7 bulan 38,88 \%,di ikuti dengan pantangan lainnya seperti berpantang makan jantung pisang 31,48 \%, berpantang makan kerak nasi dan cabai rawit 29,62 \%, makan tape 25,92 \%, makan ketan 24,07 \%, makan banyak di usia kehamilan tua 22,22 \% dan berpantang makan durian dan nenas 20,37\%. Dari wawancara dengan ibu hamil, mereka menyatakan bahwa berpantang makan ikan di usia > 7 bulan dikhawatirkan jika bersalin atau nifas nanti darah yang keluar akan berbau amis, sementara dalam teori bahwa bau amis pada masa nifas itu di akibatkan dari masa transisi perubahan lochea yang terjadi karena adanya perubahan pada bagian desidua di rahim.dan alam teori Almatsier (2009) mengenai konsep dasar ilmu gizi mengungkapkan bahwa jika dilakukan pembatasan mengenai konsumsi ikan saat kehamilan yang merupakan sumber protein dapat mengakibatkan terjadi masalah pada pembentukan dan perkembangan janin saat kehamilan, sebenarnya kandungan protein itu dalam ikan memiliki kandungan nilai protein 16,0 dan ikan juga disebutkan memiliki sumber protein hewani yang mempunyai susunan asam amino yang paling sesuai dengan kebutuhan manusia.

Mengenai berpantang makanan durian dan tape ibu hamil mengatakan dapat membahayakan kehamilan dan hal ini sejalan dalam teori Rafi (2009) mengungkapkan durian dan tape memiliki kandungan alkohol yang menghasilkan panas tubuh sehingga berpotensi menimbulkan bahaya pada janin diantaranya dapat menyebabkan perdarahan atau keguguran. Sementara untuk pantangan makan nanas yang di katakan dapat menyebabkan keguguran tidak sesuai dengan teori Rafi (2009) yang menyebutkan bahwa sebaiknya selama hamil sebenarnya bukan tidak boleh mengkonsumsi nanas tapi harus ada pembatasan konsumsi nanas yang dalam

nanas itu mengandung asam yang berlebihan sehingga dapat memacu peningkatan kadar asam lambung. 


\section{DAFTAR PUSTAKA}

1. Departemen Kesehatan Republik Indonesia. 2012. Pelatihan Kelas Ibu Kelas Ibu Hamil dan Kelas Ibu Balita Untuk Petugas Kesehatan Buku Panduan Peserta

2. Suprapto, 2006, Komplikasi Persalinan dan Risiko Kematian ibu, EGC, Jakarta

3. Wahyuna,F,2013,Gambaran Sosial Budaya Dengan Pola Makan Ibu Hamil Di Kemukiman Jangka Buya Kecamatan Jangka Buya Kabupaten Pidie Jaya Tahun 2013.Jurnal Karya Tulis ilmiah.Fitri_Wahyuna-Jurnal .pdf.di akses tanggal 26 Maret 2014.

4. Profil Kesehatan Indonesia, 2011, Cakupan Kunjungan Ibu Hamil K1, K4 Sumatera Utara ,Kementerian Kesehatan RI Tahun 2012, Jakarta.

5. Agus Hartono, dkk. Hubungan Pengetahuan Ibu, Pendidikan Ibu dan Dukungan Suami dengan Praktek Pemberian Asi Eksklusif di Kelurahan Muktiharjo Kidul Kecamatan Telogosari Kota Semarang, Jurnal Gizi Universitas Muhammadyah Semarang November 2012, Vol. 1(1) http://jurnal.unimus.ac.id

6. Nursalam. 2008. Konsep dan Penerapan Metodologi Penelitian Keperawatan Pedoma Skripsi,dan Instrumen Penelitian Keperawatan. Jakarta. Penerbit: Salemba Medika.

7. Alam, S., \& Karini, T. A. (2020). Islamic Parenting" Pola Asuh Anak: Tinjauan Perspektif Gizi Masyarakat". http://ebooks.uin-alauddin.ac.id/index.php?p=show_detail\&id=176 